•论坛・

\title{
国家公园的属性结构及其对中国本土实践的启示
}

\author{
张 机 $^{*}$ 李 釒金 \\ (华南农业大学林学与风景园林学院, 广州 510642)
}

摘要: 虽然“国家公园”概念自19世纪后半叶诞生于美国以来在全球得到了广泛传播, 但学界在国家公园本质属性 的认识上还未达成共识。基于人类对事物的认识需要依赖认识其各种属性的观点, 本文对世界各国国家公园的属 性和特征进行了对比研究, 然后从本质属性和非本质属性的理论视角构建了国家公园的属性结构。国家公园的本 质属性应包括：(1)以自然资源为主的资源类型；(2)具有国家代表性的资源价值; (3)中央或联邦政府管控的管理 体制; (4)公益性主导的资源利用。而国家公园的土地权属、面积大小、生态系统、保护重点、旅游设施、原住居 民等应列入其非本质属性的范畴。最后, 文章从国家公园的建立、治理和享用3方面探讨了国家公园属性结构对我 国本土实践的指导性意义和启示作用。坚持本质属性与非本质属性相结合的属性结构既是对世界各国国家公园建 设和管理经验的总结，也是我国将来正式设立和建设国家公园必须考虑的基本原则。

关键词: 国家公园; 属性; 属性结构; 本土实践; 可持续发展

\section{The attribute structure of national parks and its enlightenment to China's local practice}

\author{
Ji Zhang ${ }^{*}$, Xin Li
}

School of Forestry and Landscape Architecture, South China Agricultural University, Guangzhou 510642

\begin{abstract}
The concept of "national park" has been widely spread around the world since its creation in the United States in the second half of the 19th century. However, there is little consensus on the criteria needed and essential attributes that make up national parks. One of the primary ways humans identify types of things are by knowing and associating their various attributes. We present a comparative study of the attributes and characteristics of national parks around the world, and construct the attribute structure of national parks from the theoretical perspective of essential and non-essential attributes. The essential attributes of national parks should include: (1) natural resource-based; (2) national significance of natural resources; (3) management system of national government control; and (4) resource utilization led by public welfare. The land ownership, the area size, the ecosystem, the focus of conservation, the tourist facilities, as well as the indigenous residents of the national parks are considered non-essential attributes. Finally, this paper discusses the significance of this attribute structure to the establishment, governance and enjoyment of national parks in China. This attribute structure which combines essential and non-essential attributes provides both a summary of typologies of national parks globally and a foundation and decision-making tool that China must consider in the formal establishment and construction of national parks in the future.
\end{abstract}

Key words: national park; attribute; attribute structure; local practice; sustainable development

1872年美国黄石公园的建立, 标志着国家公园 (national park)作为自然保护的一种重要形式开始登 上历史舞台。随后，国家公园概念迅速传入加拿大、 澳大利亚、新西兰、南非等国, 并在20世纪扩展至
全世界。目前，全球国家公园数量已超过1,800个 (Savage, 2020)。由于中国的特殊国情, 尤其是在自 然资源保护方面存在自己惯有的管理体制，使得国 家公园理念在中国难以植根。30余年的实践证明, 
尽管我国现有的自然资源和遗产地的管理体系从 不同角度在保护和利用方面发挥了一定作用, 但多 数自然资源和遗产地的保护和开发仍存在较大问 题(陈耀华等, 2014; 苏杨, 2016)。在这一背景下, 我 国开始重新审视并借鉴西方的国家公园理念。近十 多年来, 我国关于国家公园的研究不断升温, 尤其 是云南的普达措和黑龙江的汤旺河分别于 2006年 和2008年被宣布成为“国家公园”后，不仅使国家公 园成为众多学者的研究热点, 而且也促使中央政府 开始从政策体制层面予以关注。2015年9月, 中共中 央、国务院印发的《生态文明体制改革总体方案》 提出要建立国家公园体制。两年之后，中共中央、 国务院正式印发《建立国家公园体制总体方案》(以 下简称《总体方案》), 并要求各地各部门结合实际 认真贯彻落实。2017年10月, 习近平总书记在十九 大报告中指出, 要建立以国家公园为主体的自然保 护地体系。这意味着国家公园建设作为一项国家战 略，已进入顶层部署和实施阶段。

然而, 国家公园作为自然保护地的一种模式, 虽然世界各国不同程度地借鉴了美国经验, 但由于 各国国情不同，在实践中并不能对美国模式进行简 单复制(肖练练等, 2017)。当前, 学界虽已普遍认可 国家公园属于自然保护地的一种主要类型, 但对于 国家公园的概念和属性结构的阐释仍然处于模糊 状态。在全世界范围内到底什么是国家公园? 哪些 是其本质属性(essential attribute)? 哪些又是其非本 质属性(non-essential attribute)? 明确国家公园的属 性结构对我国的本土实践有何启示作用? 等等, 这 些问题学界还未形成广泛共识。因此, 对于国家公 园属性结构的研究具有重要的理论和现实意义。

\section{基于属性视角的国家公园研突}

\section{1 “属性”的相关理论解读}

在《逻辑学大辞典》中, 属性(attribute)是指事 物本身所固有的性质及与其他事物之间的关系。任 何事物都具备一定的属性, 而任何属性都不能离开 特定的事物而单独存在。人类对客观事物的认识需 要通过认识事物的各种属性来实现, 对事物属性的 理性认识就产生该事物的概念。由于事物具有普遍 联系的特性, 因而往往具有多种属性。在事物的诸 多属性中, 有本质属性和非本质属性之分 (彭渏涟 和马钦荣, 2010)。所谓本质属性, 就是决定该事物
之所以成为该事物并区别于其他事物的特有属性。 也就是说，一个事物的本质属性是指那些不仅对该 事物起决定作用、而且能使该事物和其他事物区别 开来的属性。只有同时具备这两个条件，才能称得 上事物的本质属性(张金鉴, 1983)。而非本质属性是 指对事物不具有决定性意义的属性。虽然它也是事 物的特征之一，但并不体现事物的基本特征。因此， 为了正确地认识和了解国家公园, 必须准确把握国 家公园各方面的属性，尤其是其本质属性。

\section{2 国家公园属性的相关研究}

虽然学界很少系统探讨国家公园的属性结构 问题，但从实践者或学者们对国家公园的概念、内 涵、特征、属性、宗旨、功能、价值、管理和运营 等方面的阐释上可以看出国家公园的属性早已受 到关注。

19世纪后半叶，由于美国西部开发中的资源破 坏与浪费已威胁到美国可持续发展的基础，导致美 国民众的保护理念(conservation thinking)开始萌发, 从而掀起了美国历史上的首次自然资源保护运动。 该项运动当时涵盖三方面的内容，即以自然资源管 理为主的实用保护(utilitarian conservation)、以保护 自然风景为主的保护主义者保护(preservationist conservation)和野生动物栖息地保护(wildlife habitat protection)。正是在这一背景之下, 美国国家公园开 始创建。当时建立国家公园的主要目的是为了保护 美国西部的荒野自然和野生动物(陈金峰，2002; Schullery \& Whittlesey, 2003; Frost \& Hall, 2009)。虽 然后来英格兰和威尔士社会语境中的“国家公园”定 义与美国有所不同，但二者有一个共同特点，即把 保护自然美景和野生动物作为国家公园的主要宗 旨之一(Dower, 1945; Runte, 1973)。关于国家公园的 游恳功能和科考价值，霍布豪斯委员会 ${ }^{\circledR}$ 将高端的 游息价值视为国家公园的根本属性之一(MacEwan \& MacEwan, 1982)。世界自然保护联盟(IUCN)也指 出，国家公园应给国民提供科考、教育和游㮩的机 会(Dudley, 2008)。在我国，虽然国家公园概念引入 较晚，但早在1994年，原中华人民共和国建设部就 明确指出我国的风景名胜区与世界各国的“国家公 园”相对应(谢凝高, 2011), 兼具自然、人文景观价值

(1) 1947年, 阿瑟・霍布豪斯爵士主持召开政府委员会, 提议了12个国家 公园。详见英国《国家公园和土地使用法案》。 
和科考、文教、游悡功能(李景奇和秦小平, 1999)。 可见, 世界各种组织和学界在定义国家公园时, 都 包含壮丽的自然美景和服务公民游悡的功能, 这是 各国所认可的国家公园的基本属性。

此外, 国家公园的公益性也是学界普遍认可的 一个重要属性。在考察美国国家公园体系的产生过 程中发现, 其始终贯彻着“公益性理念”, 即将国家 公园的公益服务确定为资源的使命和功能定位(杨 锐, 2004; 苏杨和汪昌极, 2005; 孟宪民, 2007)。其他 国家也把保护自然和生态环境作为公益性事业来 管理, 并配备专门的管理人员, 经费直接由政府预 算提供(李俊生和朱彦鹏, 2015)。鉴于此，国家公园 设立的初衰应该是帮助当代人了解其自然和人文 价值, 并努力将这些宝贵资源完好无损地传承给后 代, 以实现国家公园培育国民认同感的功效(张祥 和彭夏岁, 2014; 刘红纯, 2015)。

不过, 从全世界范围来看, 关于国家公园的本 质属性仍存在一些模糊或彼此矛盾的地方。首先是 关于土地权属的问题。比如在美国, 国家公园建立 之初所提出的“荒地假设” (worthless lands hypothesis, 即国家公园往往建立在被视为没有价值的 土地之上)旨在保障国家公园都建立在国有土地之 上。后来，经各方讨论后最终确定美国国家公园的 土地所有权以及公园管理权归属于联邦政府。加拿 大的情况和美国基本相似。但在英国和新西兰则存 在不同情况。英国的国家公园存在大量私有土地 (Frost \& Hall, 2009)。在新西兰最初建立起来的公园 和保护区通常都位于土著居民毛利族人的领地之 内。此外, 在欧洲还有很多位于城市边缘地带且包 含私有土地的游㕷型国家公园。其次是关于管理体 制的问题。IUCN提出国家公园所有权和管理权通 常应置于该国最高级的权能机构。在美国, 隶属于 内政部的国家公园管理局(National Park Service, NPS)负责统管全美所有的国家公园。而澳大利亚的 管理体制与美国模式大不相同，国家公园事务不是 由联邦政府管理, 主要是由6个州政府负责设立和 运作。第三是关于资源类型的问题。IUCN在国家 公园的标准中指出, 国家公园应包含具有独特自然 风景、珍稀动植物物种及其栖息地的自然区域。美 国、加拿大和新西兰早期的国家公园大多符合这一 标准，但法国殖民当局于1924年在柬埔寨设立的 吴哥窟国家公园, 由于具有突出的文化属性和考古
价值而与其他以自然资源为主的国家公园截然不 同(Crouch \& Lübbren, 2003)。最后是关于面积的问 题。IUCN“国家公园”标准中提到国家公园应面积广 大。但澳大利亚却设立了一些面积很小的国家公园, 例如面积为 $2.25 \mathrm{~km}^{2}$ 的蒝树沟(Ferntree Gully)国家 公园, 面积为 $3.16 \mathrm{~km}^{2}$ 的塔拉沟布尔加国家公园 (Tarra Bulga National Park) (Frost \& Hall, 2009)。相 比美国黄石公园 $8,983 \mathrm{~km}^{2}$ 、南非克鲁格国家公园 $20,000 \mathrm{~km}^{2}$ ，澳大利亚的这些“迷你型”国家公园则 成为另类。

要解决国家公园究竟“是什么”和“怎么建”等问 题, 就必须正确认识国家公园的各种属性尤其是本 质属性。综上所述，目前世界各国对于国家公园的 内涵或属性的探讨仍然存在不清晰甚至彼此矛盾 之处。我国学者对国家公园的本质属性也进行了各 自的概括，比如“以自然保护为主” “生态保护第一” “公益性”“科学性”“国家代表性”“国家主导性”等 (唐芳林, 2014a; 田美玲和方世明，2017; 杨锐等, 2019), 但这些表述都不够准确或全面。可以说，在 属性界定上的模糊和矛盾是各国在国家公园本土 化实践中存在诸多问题的主要原因。因此，有必要 对国家公园的科学内涵或属性, 即属性结构进行系 统梳理，这样既有利于明确国家公园的概念，更有 利于国家公园的理论和实践在世界范围内更好地 推广。

\section{国家公园的属性结构及其阐程}

国家公园的概念虽已得到国际社会的广泛认 可，但与生物圈保护区(Biosphere Reserves)或世界 遗产管理体系(Management System of World Heritage Sites)相比，没有一个国际体制来认证“国家公 园”。随着环境的变迁，国家公园的概念也随之发生 变化, 各国为适应各自国情或满足各自需求而改造 了这个概念(Frost \& Hall, 2009; 唐芳林, 2014b)。究 其原因，在于国际社会对国家公园的属性尤其是本 质属性的认识还未达成共识。逻辑学认为, 要深刻 地认识和把握事物、形成有关事物的科学概念，就 必须揭示和把握事物的本质属性(彭渏涟和马钦荣, 2010)。那么，国家公园的本质属性是什么? 通过前 文的述评以及对世界范围内各类国家公园进行考 察与分析，笔者重新梳理了国家公园的属性，并从 本质属性和非本质属性的视角构建了国家公园的 


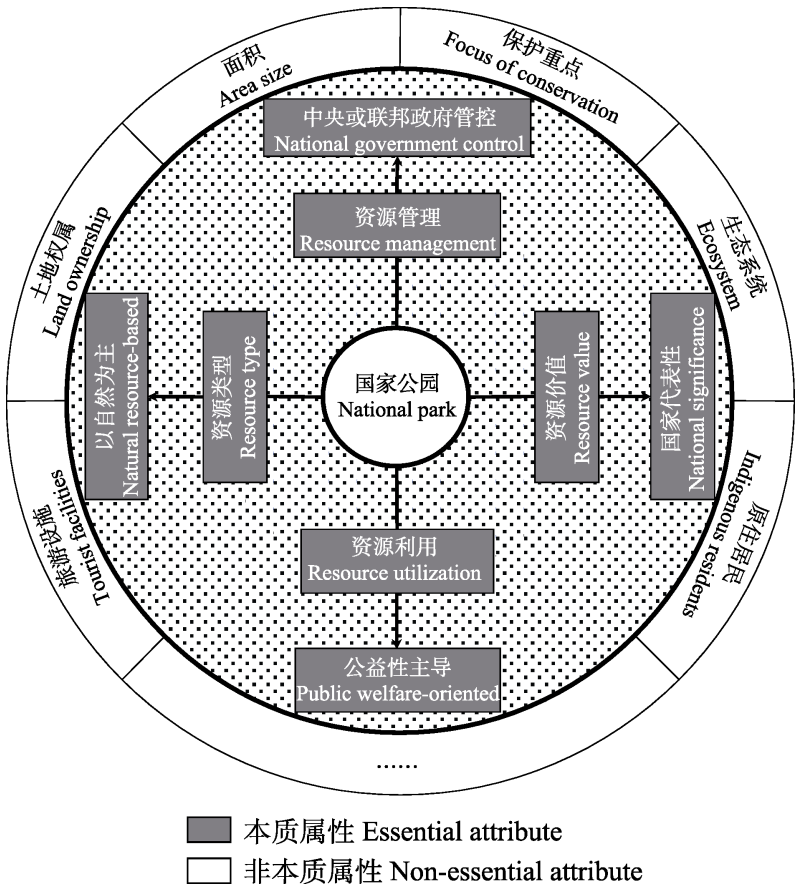

图1 国家公园的属性结构

Fig. 1 Attribute structure of national parks

属性结构(图1)。其中，国家公园的本质属性应包括: (1)资源类型：以自然为主; (2)资源价值：具有国家 代表性; (3)资源管理: 中央或联邦政府管控; (4)资 源利用: 公益性主导。国家公园的其他属性则放入 结构的外圈层, 属于国家公园的非本质属性层面。

\section{1 国家公园的本质属性}

(1)以自然资源为主的资源类型。虽然很多国家 承认文化遗产是国家公园不可或缺的组成部分, 但 国家公园的资源类型应以自然资源为主。1872年美 国国会发布的《建立黄石国家公园法案》(Act Establishing Yellowstone National Park)提出设立黄 石公园是为了保护自然奇观和不朽的美景。作为世 界上的第一个国家公园, 黄石的原则影响着后来国 家公园的发展。以至于世界上绝大多数国家公园都 集中在具有丰富自然资源和壮丽自然景观的地区, 都以自然资源为主, 文化遗迹只是附属其中的一小 部分。在中国，悠久的历史和“天人合一”的山水观 让许多壮美的自然景观都留有人文痕迹, 比如山顶 总会见到道观庙宇、亭台楼阁等，悬崖峭壁处常可 见文人墨客留下的石刻等等。但这些特征并不与 “以自然资源为主”这一本质属性相冲突。三江源、 东北虎豹、大熊猫、神农架、武夷山等作为中国国 家公园体制试点，也体现了以自然资源为主的本质
属性。

(2)具有国家代表性的资源价值。国家公园既然 是国家层面批准设立的保护区域，其自然资源应具 有国家代表性。“国家代表性”是指国家公园内的资 源具有国家层面的战略意义，在资源的独特性和重 要性方面能代表一个国家的形象，例如美国约塞米 蒂 (Yosemite National Park) 的巨型红杉 (Sequoia sempeervirens)、加拿大班夫的温泉、澳大利亚乌鲁 鲁的巨石、中国的大熊猫(Ailuropoda melanoleuca) 等等。这样的资源往往在国内乃至世界上具有较大 知名度，保护和利用这些资源具有极其重要的综合 价值。IUCN在国家公园的管理目的中提到，为了实 现其精神、科考、教育和游憩的功能，应保护具有 全国甚至国际性重要意义的自然资源。不过，这里 需要说明一下，到底什么样的资源才算具有国家或 国际意义? 事实上，这个属性是 4 个本质属性中最 具灵活性的一项，它是相对而言的，要根据各国资 源的具体情况确定。

(3)中央或联邦政府管控的管理体制。通过对世 界范围内国家公园管理体制的考察，笔者认为，国 家公园应坚持采用中央或联邦政府管控的管理体 制。首先，国家公园的资格或称号应由中央或联邦 政府批准授予。《建立黄石国家公园法案》中明确 指出，国家公园资格应由国家级政府授予。其次, 国家公园的管理权限应放置在中央或联邦政府层 级。IUCN指出，国家公园的所有权和管理权通常应 置于该国最高级的权能机构(Frost \& Hall, 2009)。采 取中央或联邦政府管控的管理体制，可以有效统筹 自然资源的保护与利用，确保其可持续发展。但需 要注意的是，国家公园管理的具体事务可以由中央 或联邦政府委托给地方政府，也可以设置直属于中 央或联邦政府的专门管理机构来负责，甚至还可以 允许当地居民参与管理。

(4)公益性主导的资源利用。国家公园作为全体 公民的共同财富，在资源利用时应坚持以公益性为 主导。这里所讲的资源主要是指能满足国民游頽、 科考和教育等需要的自然和文化资源，它并不包括 国家其他资源比如矿产等。而国家公园语境下的资 源利用不同于一般性的资源利用，它主要是指在不 破坏自然生态系统的前提下进行限制性的旅游资 源利用。以公益性为主导是指在国家公园资源的利 用和享用过程中要依法维护公众利益, 体现国家公 
园的非营利性特点, 充分发挥其社会效益。尤其是 在门票制度方面, 应采取低门票或免门票的方式, 让全体公民不论收入水平高低, 都能公平享用国家 公园, 以实现国家公园的综合价值。公益性作为国 家公园设立的根本目的(陈耀华等, 2014; 汪德根和 Lew, 2015), 既是国家公园应有的本质属性(李春晓 和于海波, 2015; 唐芳林, 2017; 张玉钧和张海霞, 2019), 也是国家公园所具有的一种价值属性(马志 政，1986)。因此, 若要体现以公益性为主导的资源 利用, 就必须确保国家公园由中央或联邦政府直接 管控，这与前面提到的“中央或联邦政府管控的管 理体制”具有内在统一性。

\section{2 国家公园的非本质属性}

从世界范围来看, 由于各国国情不一样, 各个 国家在创建国家公园的过程中出现了不同情况或 问题，本文将其归为国家公园的非本质属性(图1)。 首先是关于国家公园的面积问题。虽然IUCN指出 国家公园应面积广大, 但由于各个国家的国土面积 以及建立国家公园的迫切性需求各不相同, 面积不 应成为限制国家公园建立的属性条件。其次是关于 土地权属问题。纵观世界各国, 土地权属不应成为 判断国家公园的依据。虽然美国、加拿大等国的国 家公园土地所有权都归联邦政府所有, 但欧洲很多 国家公园包含有私有土地。第三, 国家公园内是否 存在原住民居住, 各国也情况不一。比如美国、加 拿大等国的大部分国家公园内没有原住民，而澳大 利亚和新西兰等则大多存在原住民的问题。第四, 国家公园的保护重点具有多样性。例如, 美国约塞 米蒂国家公园是为了保护以巨型红杉为代表的森 林植被, 加拿大班夫国家公园是为了保护班夫火车 站附近的落基山热矿泉, 澳大利亚大堡礁海洋公园 是为了保护世界上面积最大的珊瑚礁生态系统等 等。第五, 生态系统的数量和完整性、旅游基础设 施和接待服务设施的完善程度等也因各国国家公 园具体情况而呈现出各种差异, 不应将其列入国家 公园的本质属性。

需要指出的是, 国家公园的非本质属性作为各 国建设国家公园的特殊性质, 与前文所提到的国家 公园的本质属性并不冲突。本质属性是世界各国国 家公园存在的普遍属性, 它构成了国家公园概念中 最基本的内涵。而非本质属性是对国家公园形态的 丰富和发展。因此, 只有遵循本质属性与非本质属
性相统一, 才能使得国家公园模式在世界范围内生 根落地, 也才能使国家公园建设在实践和理论层面 存在对话的可能性。

\section{国家公园属性结构对中国本土实践的启示}

从2015年开始启动国家公园试点工作到2017 年底, 我国已设立10个国家公园体制试点, 总面积 达 22.29 万 $\mathrm{km}^{2}$, 涉及 12 个省份。近 5 年来, 试点工作 取得了许多实质性进展，为2020年基本完成国家公 园体制试点任务、正式设立一批国家公园打下了良 好基础。但由于国际上对国家公园属性结构的界定 模糊不清以及我国特殊的保护区体制，使得国家公 园在我国的本土实践仍存在许多挑战。这里所讲的 本土实践不仅是指我国国家公园的试点实践，更重 要的是指2020年试点结束后国家公园在我国生根 落地的全面实践，包括国家公园的建立、治理和享 用3方面。我们认为, 本文所建构的国家公园属性结 构对将来的全面实践具有一定的指导性意义和启 示作用。

\section{1 国家公园的建立}

(1)国家公园的概念界定问题。到底怎么界定国 家公园的概念? 这需要我们抓住国家公园的本质 属性。前文指出, 4 个本质属性是国家公园概念的内 核，贯穿国家公园的建立、治理和享用的全过程。 也就是说，如果某个国家公园在任何一个过程或阶 段因某种因素导致其某个本质属性的缺失，那么它 将不再是国家公园。

(2)设立和管理的主体问题。根据国家公园属性 结构中的第三条本质属性，设立和管理国家公园的 主体应是中央或联邦政府。《总体方案》中也明确 指出，国家公园应由国家批准设立并且主导管理。

《关于建立以国家公园为主体的自然保护地体系 的指导意见》指出，到2020年，我国将正式设立一 批国家公园。那么, 国家公园必须经由我国最高级 别的权能机构(隶属于自然资源部下面的“国家公园 管理局”)进行授权和批准才能成立。并且，国家公 园设立之后的管理主体同样应该是国家公园管理 局及其下属机构。

(3)遴选标准问题。国家公园的遴选标准是要解 决哪些区域可以设立国家公园的问题。本文所界定 的国家公园属性结构在资源类型和资源价值两方 面对遴选标准将起到一定的启示和指导作用。即国 
家公园的资源类型应以自然资源为主，资源价值应 具有国家代表性。目前, 已经有一些文章开始探讨 国家公园的入选标准问题(田美玲和方世明，2017; 杨锐, 2018; 陈君帜等, 2019; 李明虎等, 2019; 虞虎 和钟林生, 2019)。但我们认为, 国家公园的入选标 准不能与国家公园的本质属性相违背。当然, 国家 公园入选标准不仅仅涉及到资源类型和价值的问 题, 还需要考虑方方面面的其他具体事项。总之, 这项工作需要在2020年正式设立国家公园之前抓 紧完成(唐芳林等, 2019)。

\section{2 国家公园的治理}

(1)健全国家公园的管理体制。国家公园的本质 属性要求我们要坚持中央政府统一管控的垂直管 理体制。我国自然资源管理体制的混乱问题在前一 阶段的试点工作中引起了重视, 比如2018年我国组 建了国家林业和草原局, 加挂了国家公园管理局牌 子; 一些省份针对具体的国家公园试点组建了各自 的国家公园管理局等等。但在前期的试点工作中还 存在一些问题，比如垂直管理体制与运行机制尚不 顺畅，如各级管理机构人员编制不明晰、日常管理、 综合执法、经营监管等工作机制尚未落地等(陈雅如 等, 2019)。此外，已经成立的一些基层管理机构的 名称都含有“国家公园管理局”，比如“大熊猫国家 公园管理局” “湖南南山国家公园管理局” “东北虎 豹国家公园管理局”等，这种命名是否合适值得商 榷。如果要建立垂直的三级管理架构(陈曦, 2019), 我们建议由上到下依次为“国家公园管理局”(国家 级)、“国家公园某某省分局”(省级)和“某某国家公园 管理处”(基层)。然后在此基础上落实各级机构的人 员编制、日常管理与监管执法等机制问题。

(2)加强国家公园的法制建设。在本文界定的国 家公园属性结构中, 资源的管理和利用都离不开法 治。要通过国家立法来实现国家公园的严格保护, 确保用法治思维与法治手段来协调自然保护地体 系建设过程中复杂的功能矛盾与多元利益冲突, 使 国家公园的管理体制具有法律的权威性(吕忠梅, 2019; 唐芳林等, 2019)。目前, 《国家公园法》已经 被列入全国人大立法计划, 在国家公园体制改革试 点结束后即将成为适用于所有国家公园的综合性 基本法。它的基本内容应该涵盖国家公园的功能定 位、保护目标、管理体制、设立标准、资金筹措、 公众参与和特许经营等基础性、框架性、统一性的
规定(秦天宝和刘䝩彤, 2019)。此外，我国在试点阶 段开展的“一园一法”工作能为《国家公园法》提供 法理研究和实践经验，但它绝不是国家公园体制建 设的最终立法形态，而只是暂时的过渡性安排。

(3)创新国家公园的运营管理机制。受国家公园 的公益性原则启发, 对国家公园这样的准公共物品 的供给, 要充分发挥政府、市场以及社会的积极性 (余梦莉, 2019)。在国家公园的具体经营过程中, 要 积极探索建立多渠道、多形式的资金投入机制，广 泛吸取民间团体、企业、个人等社会资本投入国家 公园的建设和管理, 以减轻财政负担(王毅和黄宝 荣，2019)。首先，要建立健全具有中国特色的国家 公园特许经营制度。比如签订特许权合同、发放许 可证、签订地役权合同等，可以成为我国国家公园 特许制度的基本实现途径(吴承照和陈涵子, 2019)。 其次, 可通过志愿服务系统减轻国家公园的人力投 入。引进志愿者团队, 不仅能减轻国家公园的人力 支出, 还能通过扩大公众参与度加深社会对国家公 园的了解与支持(王辉等, 2016)。

(4)健全国家公园的资金保障机制。我国国家公 园试点期间在资金保障方面存在的问题主要有资 金投入渠道单一、资金使用投向不科学、社会资金 的投入与管理体系还未建立等(陈雅如等, 2019)。为 了实现国家公园的公益性目标以及实现国家公园 保护自然生态系统原真性和完整性的首要功能(代 云川等，2019)，必须健全国家公园的资金保障机 制。一是加大中央财政的支持力度。按照“中央事 权由中央政府出资保障”的原则，设立国家公园中 央预算内投资专项和中央财政专项资金(陈雅如等, 2019)。二是积极建立国家公园的社会捐赠制度。从 国外来看, 美国、日本等在这方面做得比较成熟(谷 光灿和刘智, 2013; 王连勇和Steven, 2014; 赵继敏 和王洁，2014)。但在我国，社会募捐和慈善捐赠事 业主要集中在自然灾害或灾难、教育、医疗、宗教 等方面，而在自然资源的保护方面几乎没有起步。 随着我国对国家公园建设的重视，媒体的宣传将进 一步扩大国家公园的知名度和品牌价值，从而可以 推测, 社会捐赠事业在这方面的拓展空间巨大。

\section{3 国家公园的享用}

(1)坚持国家公园的公益性原则。前文论及的国 家公园本质属性之一便是国家公园的资源利用要 坚持以公益性为主导。其目的就是让国家公园建设 
和发展的成果惠及全体国民。1872年美国建立黄石 国家公园的目的就是要将其建成为“一个为了公众 利益和人民享乐的公园或娱乐场所” ““a public park or pleasuring-ground for the benefit and enjoyment of the people”)。为了实现这个目标, 美国有专门的立 法来规定国家公园门票的收费标准、原则、最高限 额以及哪些国家公园不允许收费或者哪些访客应 免费参观(刘鹏飞等, 2011)。因此, 我国将来正式设 立国家公园之后，应该效仿美国、加拿大、日本、 新西兰和英国等的做法, 通过采取低价门票或免门 票的办法更好地满足国民进行游息和娱乐的需要, 实现国家公园的国民精神教育和自然文化综合价 值。而要实现这一公益性目标, 就必须在前面两个 环节中做好相关工作，尤其是法制建设和资金保障 两个方面。

(2)调动当地居民共建共享的积极性。当地居民 的利益与国家公园息息相关。我们不仅要让当地居 民成为国家公园的建设者, 而且更重要的是要让他 们成为国家公园利益的享受者(何思源等, 2020)。建 设是为了更美好地享受, 享受是为了更积极地建设, 二者互为条件, 相辅相成。设立生态管护公益岗位, 是我们在国家公园试点工作中探索出来的一条宝 贵经验, 要继续坚持和完善。据调查, 《三江源国 家公园总体规划》规定要设置生态管护岗位16,621 个, 预计每年在公益岗位上的投入达到 4 亿元(马晓 东和王冰洁, 2019)。生态管护公益岗位的设置一方 面可以提高当地居民保护生态的使命感和责任感， 另一方面可以通过增加他们的收入使其更积极地 投入国家公园的保护和建设。

(3)发挥国家公园的科研和解说教育功能。国家 公园除了游憩功能以外, 还具有十分重要的科研和 解说教育功能。国家公园内的自然资源十分丰富, 为地质学、生态学、生物多样性保护研究提供了天 然的科研平台。国家公园可以通过与科研机构、高 校合作, 实现研究资源的共享, 其科研成果又可以 反过来服务于国家公园的建设和管理。因此, 国家 公园应该在公益性目标的统领下以及《国家公园 法》的保障下, 无偿地为专业人士提供科研服务, 充分发挥国家公园的科研功能。此外, 国家公园管 理方可以聘请专业人士、在校大学生(实习生)和当 地居民担任志愿向导和讲解员, 向国家公园的大众 访客介绍生态知识和当地特有的动植物等, 以实现
国家公园的解说和教育服务功能。

\section{结论}

通过总结和对比各国国家公园的建设和管理 实践，本文从本质属性和非本质属性的视角构建了 国家公园的属性结构，以促进我国在建设自己的国 家公园时能秉持求同存异的立场正确看待世界各 国模式，有助于国家公园在我国扎根落地。国家公 园概念的科学内涵应包括 4 个本质属性，即以自然 资源为主的资源类型、具有国家代表性的资源价 值、中央或联邦政府管控的管理体制和公益性主导 的资源利用。而土地权属、面积大小、生态系统、 保护重点、旅游设施、原住居民等，则可列入国家 公园的非本质属性范畴。非本质属性与本质属性并 不矛盾，在坚持本质属性的前提下允许非本质属性 的存在，有利于世界各国国家公园的建设和发展。 由于本文所构建的属性结构是对世界各国积累的 建设和管理经验的总结和归纳，因此不管是在国 家公园的建立、治理还是享用方面，它都将对我国 国家公园的本土实践具有重要的指导意义和启示 作用。

然而，我国国家公园的建设作为一项复杂的系 统工程, 还有许多理论和实践问题尚待深入研究, 比如如何正本清源以建立完整的国家公园体系? 如何破旧立新以完善国家公园的管理体制? 如何 回归初心以确保国家公园的公益性原则？如何集 思广益以创新国家公园的经营机制? 再比如我国 国家公园的遴选标准与技术指标体系该如何制定? 如何围绕国家公园的建设和管理建立健全我国国 家公园的法律体系? 如何通过政府、企业和媒体的 力量塑造国家公园的“国”字号品牌并挖掘其潜在价 值? 如何推动社会捐助事业融入国家公园的建设 和管理？此外，党的十九大报告明确提出“建立以 国家公园为主体的自然保护地体系”, 那么如何衔 接国家公园与现有自然保护地的关系? 等等。笔者 相信，随着《总体方案》的全面落实以及学界对相 关理论和实践问题广泛而深入的探讨，我国国家公 园的发展将迎来新的局面。

\section{参考文献}

Chen JZ, Ni JW, Tang XP, Liang BK, Wang S (2019) Research on the construction of Chinese national park standard 
system. Forest Resources Management, (6), 1-6. (in Chinese with English abstract) [陈君帜, 倪建伟, 唐小平, 梁兵宽, 王澍 (2019) 中国国家公园标准体系构建研究. 林业资 源管理, (6), 1-6.]

Chen X (2019) Difficulties and countermeasures in the management mode of the pilot project of national park system in Hainan. Hainan Today, (1), 63-64. (in Chinese) [陈曦 (2019) 海南国家公园体制试点建设管理模式难点 问题与对策. 今日海南, (1), 63-64.]

Chen XF (2002) National park system of USA and its resource criteria and the procedure of appraisement and authorization. World Forestry Research, 15(5), 49-55. (in Chinese with English abstract) [陈金峰 (2002) 美国国家公园体系及其 资源标准和评审程序. 世界林业研究, 15(5), 49-55.]

Chen YH, Huang D, Yan SQ (2014) Discussions on public welfare, state dominance and scientificity of national park. Scientia Geographica Sinica, 34, 257-264. (in Chinese with English abstract) [陈耀华, 黄丹, 颜思琦 (2014) 论国家 公园的公益性、国家主导性和科学性. 地理科学, 34, 257-264.]

Chen YR, Han JK, Qin LN, Yang HC (2019) The problems and development approach of the Northeast Tiger and Leopard National Park System Pilot. Environmental Protection, 47(14), 61-65. (in Chinese) [陈雅如, 韩俊魁, 秦岭南, 杨 怀超 (2019) 东北虎豹国家公园体制试点面临的问题与 发展路径研究. 环境保护, 47(14), 61-65.]

Crouch D, Lübbren N (2003) Visual Culture and Tourism. Berg Publishers, Oxford.

Dai YC, Xue YD, Zhang YY, Li DQ (2019) Summary comments on assessment methods of ecosystem integrity for national parks. Biodiversity Science, 27, 104-113. (in Chinese with English abstract) [代云川, 薛亚东, 张云毅, 李迪强 (2019) 国家公园生态系统完整性评价研究进展. 生物多样性, 27, 104-113.]

Dower J (1945) Report on National Parks in England and Wales. HMSO, London.

Dudley N (2008) Guidelines for Applying Protected Area Management Categories. IUCN, Gland, Switzerland.

Frost W, Hall CM (2009) Tourism and National Parks: International Perspectives on Development, Histories and Change. Routledge, London.

Gu GC, Liu Z (2013) The conservation and administration of national parks of Japan by the case study of the original point of nature conservation of Oze. Chinese Landscape Architecture, 29(8), 109-113. (in Chinese with English abstract) [谷光灿, 刘智 (2013) 从日本自然保护的原点 一尾濑出发看日本国家公园的保护管理. 中国园林, 29(8), 109-113.]

He SY, Wei Y, Su Y, Min QW (2020) Guaranteeing fair and sustainable benefit sharing for communities in the national park: A study from perception of meanings of social-ecological systems. Acta Ecologica Sinica, 40, 2450-2462. (in Chinese with English abstract) [何思源, 魏钰, 苏杨, 闵庆
文 (2020) 保障国家公园体制试点区社区居民利益分享 的公平与可持续——基于社会-生态系统意义认知的研 究. 生态学报, 40, 2450-2462.]

Li CX, Yu HB (2015) National Park: Exploring the Road of China. China Tourism Press, Beijing. (in Chinese) [李春晓, 于海波 (2015) 国家公园——探索中国之路. 中国旅游 出版社, 北京.]

Li JQ, Qin XP (1999) Comparison of national park system in USA and Chinese scenic spots. Chinese Landscape Architecture, 15(3), 70-73. (in Chinese) [李景奇, 秦小平 (1999) 美国国家公园系统与中国风景名胜区比较. 中国 园林, 15(3), 70-73.]

Li JS, Zhu YP (2015) Discussion on national park funds safeguard mechanism. Environmental Protection, 43(14), 38-40. (in Chinese) [李俊生，朱彦鹏 (2015) 国家公园资 金保障机制探讨. 环境保护, 43(14), 38-40.]

Li MH, Dou YQ, Hu SF, Li Y, Liu KS (2019) Research on the selection mechanism and construction standards of national parks in China: Based on foreign enlightenments and experiences. World Forestry Research, 32(2), 83-89. (in Chinese) [李明虎, 窦亚权, 胡树发, 李娅, 刘柯三 (2019) 我国国家公园遴选机制及建设标准研究——基于国外的 启示与经验借鉴. 世界林业研究, 32(2), 83-89.]

Liu HC (2015) References of national park legal system in main countries. Chinese Landscape Architecture, 31(11), 73-77. (in Chinese with English abstract) [刘红纯 (2015) 世界主要国家国家公园立法和管理启示. 中国园林, 31(11), 73-77.]

Liu PF, Liang LK, Liu Y (2011) A comparative study on admission tickets price between national scenic resort in China and national park in the United States. Areal Research and Development, 30(5), 108-111, 122. (in Chinese with English abstract) [刘鹏飞, 梁留科, 刘英 (2011) 中美国 家风景名胜区门票价格比较研究. 地域研究与开发, 30(5), 108-111, 122.]

Lü ZM (2019) Systematic legislation for nature conservation with national parks as the main body. Biodiversity Science, 27, 128-136. (in Chinese with English abstract) [吕忠梅 (2019) 以国家公园为主体的自然保护地体系立法思考. 生物多样性, 27, 128-136.]

Ma XD, Wang BJ (2019) A brief analysis of the management institutional innovation in the national park system: A case of Sanjiangyuan National Park. Journal of Xi'an University of Architecture \& Technology (Social Science Edition), 38(3), 58-62. (in Chinese with English abstract) [马晓东, 王冰洁 (2019) 浅析国家公园体系管理体制中的制度创 新——三江源国家公园为例. 西安建筑科技大学学报 (社会科学版), 38(3), 58-62.]

Ma ZZ (1986) On value attribute. Philosophical Researches, (1), 64-68. (in Chinese) [马志政 (1986) 论价值属性. 哲 学研究, (1), 64-68.]

MacEwan M, MacEwan A (1982) National Parks: Conservation or Cosmetic. George Allen and Unwin, London. 
Meng XM (2007) Management experience of American national park system: Discussing the inspiration to China's scenic spots. World Forestry Research, 20(1), 75-79. (in Chinese with English abstract) [孟宪民 (2007) 美国国家 公园体系的管理经验——兼谈对中国风景名胜区的启示. 世界林业研究, 20(1), 75-79.]

Peng YL, Ma QR (2010) The Dictionary of Logic. Shanghai Dictionary Press, Shanghai. (in Chinese) [彭猗涟, 马钦荣 (2010) 逻辑学大辞典. 上海辞书出版社, 上海.]

Qin TB, Liu TT (2019) Myths and solutions of the "one park, one law" model in the legislation of national park. Journal of China University of Geosciences (Social Sciences Edition), 19(6), 1-12. (in Chinese with English abstract) [秦天宝, 刘 䑣䑣 (2019) 国家公园立法中 “一园一法” 模式之迷思与 化解. 中国地质大学学报(社会科学版), 19(6), 1-12.]

Runte A (1973) 'Worthless' lands-our national parks: The enigmatic past and uncertain future of America's scenic wonderlands. American West, 10, 4-11.

Savage J (2020) How many national parks are there on earth. https://www.answers.com/Q/How_many_national_parks_are_ there_on_earth/. (accessed on 2020-02-09)

Schullery P, Whittlesey L (2003) Myth and History in the Creation of Yellowstone National Park. University of Nebraska Press, Lincoln.

Su Y (2016) What are the difficulties in the construction of national parks. China Environment News, 2016-01-18(2). (in Chinese) [苏杨 (2016) 国家公园体制建设难点在哪 儿? 中国环境报, 2016-01-18(2).]

Su Y, Wang CJ (2005) The management experience of American natural and cultural resources and its enlightenment to China. Chinese Landscape Architecture, (8), 46-53. (in Chinese with English abstract) [苏杨, 汪昌极 (2005) 美国 自然文化遗产管理经验及对中国有关改革的启示. 中国 园林, (8), 46-53.]

Tang FL (2014a) The desired national park in China. Forestry Construction, (5), 1-7. (in Chinese with English abstract) [唐芳林 (2014a) 中国需要建设什么样的国家公园. 林业 建设, (5), 1-7.]

Tang FL (2014b) Analysis on national park attributes \& preliminary research on approaches of establishing national park system. Forestry Construction, (3), 1-8. (in Chinese with English abstract) [唐芳林 (2014b) 国家公园属性分 析和建立国家公园体制的路径初探. 林业建设, (3), 1-8.]

Tang FL (2017) National Park Theory and Practice. China Forestry Publishing House, Beijing. (in Chinese) [唐芳林 (2017) 国家公园理论与实践. 中国林业出版社, 北京.]

Tang FL, Yan Y, Liu WG (2019) Construction progress of national park system in China. Biodiversity Science, 27, 123-127. (in Chinese with English abstract) [唐芳林, 间颜, 刘文国 (2019) 我国国家公园体制建设进展. 生物多样 性, 27, 123-127.]

Tian ML, Fang SM (2017) A review of national park selection criteria system in China: A case study of 9 national park experimental areas. World Forestry Research, 30(5), 62-68. (in Chinese with English abstract) [田美玲, 方世明 (2017) 中国国家公园准入标准研究述评—以9个国家公园体 制试点区为例. 世界林业研究, 30(5), 62-68.]

Wang DG, Lew AA (2015) The return of public welfare and the reform of management system in national park "admission economy”. Tourism Tribune, 30(5), 11-13. (in Chinese with English abstract) [汪德根, Lew AA (2015) 国家公 园“门票经济”的公益性回归与管理体制改革. 旅游学刊, 30(5), 11-13.]

Wang H, Liu XY, Guo JK, Sun CZ (2016) Volunteer service and mechanism in the U.S. national parks: A case study of Channel Islands National Park. Geographical Research, 35, 1193-1202. (in Chinese with English abstract) [王辉, 刘小 宇, 郭建科, 孙才志 (2016) 美国国家公园志愿者服务及 机制——以海峡群岛国家公园为例. 地理研究, 35, 1193-1202.]

Wang LY, Steven H (2014) Building a unified Chinese national park system: Historical lessons learned from the United States. Geographical Research, 33, 2407-2417. (in Chinese with English abstract) [王连勇, Steven H (2014) 创建统一 的中华国家公园体系一美国历史经验的启示. 地理研 究, 33, 2407-2417.]

Wang Y, Huang BR (2019) Institutional reform for building China's national park system: Review and prospects. Biodiversity Science, 27, 117-122. (in Chinese with English abstract) [王毅, 黄宝荣 (2019) 中国国家公园体制改革: 回顾与前瞻. 生物多样性, 27, 117-122.]

Wu CZ, Chen HZ (2019) The framework of China national park concession system. Chinese Landscape Architecture, 35(8), 12-16. (in Chinese with English abstract) [吴承照, 陈涵子 (2019) 中国国家公园特许制度的框架建构. 中 国园林, 35(8), 12-16.]

Xiao LL, Zhong LS, Zhou R, Yu H (2017) Review of international research on national parks as an evolving knowledge domain in recent 30 years. Progress in Geography, 36, 244-255. (in Chinese with English abstract) [肖练练, 钟林 生, 周飸, 虞虎 (2017) 近30年来国外国家公园研究进展 与启示. 地理科学进展, 36, 244-255.]

Xie NG (2011) Famous Mountain Scenery Heritage: Xie Ninggao Collection. Zhonghua Book Company, Beijing. (in Chinese) [谢凝高 (2011) 名山风景遗产: 谢凝高文集. 中 华书局, 北京.]

Yang R (2004) American national parks selection criteria and directive document system. World Forestry Research, 17(2), 35-36. (in Chinese) [杨锐 (2004) 美国国家公园入选标准 和指令性文件体系. 世界林业研究, 17(2), 35-36.]

Yang R (2018) Criteria for designation of China's national park. Forestry Construction, (5), 103-112. (in Chinese) [杨 锐 (2018) 中国国家公园设立标准研究. 林业建设, (5), 103-112.]

Yang R, Shen XL, Ma KP (2019) Recommendations on building up China's national-park-centric protected area system. 
Biodiversity Science, 27, 137-139. (in Chinese) [杨锐, 申 小莉, 马克平 (2019) 关于贯彻落实“建立以国家公园为 主体的自然保护地体系”的六项建议. 生物多样性, 27, 137-139.

Yu H, Zhong LS (2019) Discussion on the selection criteria of national parks in China based on international experience. Acta Ecologica Sinica, 39, 1309-1317. (in Chinese with English abstract) [虞虎, 钟林生 (2019) 基于国际经验的 我国国家公园遴选探讨. 生态学报, 39, 1309-1317.]

Yu ML (2019) On the co-construction, co-governance and sharing of the national park system. Journal of Central South University of Forestry \& Technology (Social Sciences), 13(5), 25-32. (in Chinese with English abstract) [余梦莉 (2019) 论新时代国家公园的共建共治共享. 中南林业科 技大学学报(社会科学版), 13(5), 25-32.]

Zhang JJ (1983) Is there an "essential attribute" shared by many things? Logic and Language Learning, (5), 21. (in Chinese) [张金鉴 (1983) 有许多事物共有的“本质属性” 吗? 逻辑与语言学习, (5), 21.]
Zhang X, Peng XS (2014) Tourism development strategy innovation in the southern slope region of the Tianshan Mt. Tomur. Journal of Arid Land Resources and Environment, 28, 199-203. (in Chinese with English abstract) [张祥, 彭 夏岁 (2014) 天山托木尔峰南坡地区旅游发展模式创新 研究. 干旱区资源与环境, 28, 199-203.]

Zhang YJ, Zhang HX (2019) Regulation of recreational use in national parks. Tourism Tribune, 34(3), 5-7. (in Chinese) [张玉钧, 张海霞 (2019) 国家公园的游憩利用规制. 旅 游学刊, 34(3), 5-7.]

Zhao JM, Wang J (2014) Management reform by foreign national parks under the background of new public management movement: Experiences and inspiration on China. World Forestry Research, 27(5), 44-49. (in Chinese with English abstract) [赵继敏, 王洁 (2014) 新公共管理背景 下国外国家公园管理改革的经验与启示. 世界林业研究, 27(5), 44-49.]

(责任编委: 徐卫华 责任编辑: 黄祥忠) 